\title{
Interment of ashes: Cremation service
}

\author{
Maake Masango \\ Department of Practical Theology \\ University of Pretoria
}

\begin{abstract}
This article develops a liturgy of worship service which is to be conducted at the crematorium. This interment of ashes service can also take place at the church in the garden of remembrance. The aim of this service is to help members of the family achieve closure as far as the issue of the ashes of their loved one is concerned. The liturgy developed is focused on a continuation of the pastoral elements which aim to take care of the souls of those who are bereaved.
\end{abstract}

\section{INTRODUCTION}

Interment of ashes: Cremation service ${ }^{1}$

The prevalence of cremation is causing South Africans to think of cremation as an alternative way of burial; what needs to be redefined, is the associated ceremony/order of service or liturgy. This topic has been dealt with in a major article in HTS 61(4), November 2005. The aim of the current article is to create a liturgy and order of service which would be of assistance to African ministers when having to deal with liturgy and the service of cremation.

Liturgy functions as a means of helping people to cope with life's most difficult circumstances, especially bereavement. Hiltner commented as follows on rituals, especially with regard to the issue of liturgy:

Rituals give meaning to the changes in the status or role of persons, they re-establish equilibrium in persons and communities after the crisis of change, and they serve the educational function of transmitting to future generations what the community believes to be the meaning of that change.

(Hiltner 1949:71)

\footnotetext{
${ }^{1}$ This article is a follow-up of a research paper published in HTS 61(4), November 2005, entitled "Cremation a problem to African people".
} 
In other words, crucial moments in life, such as birth, marriage, vocation, and death are accompanied by a complex series of rituals and liturgical acts. Generally speaking, the more threatening and potentially disruptive the crisis, the more detailed and carefully patterned the ritual is which addresses the crisis. Rituals in an African community relate to crises such as death and also contain therapeutic healing elements. As Africans face death, rituals help them to deal with death and mourning, as well as bereavement. In short, these can be described as rites of passage followed when a family is faced with death. In this regard, the rituals associated with the wake, the viewing of the body, the graveside service, even the actual burying of the coffin, or the cremation service play an important role. These can be visible or acted means of coming to terms with the separation that death brings. By avoiding such separation is merely to postpone the necessary first step in the process of grief and to run the risk of prolonging the pain of grief, or of dealing with grief in less productive ways. The reader needs to be aware of the fact that the rites of passage associated with death or cremation are in a process of transition. The actual topic of cremation has been dealt with and published in HTS 61(4) 2005. This follow-up article will therefore concentrate on creating a liturgy or service of cremation. In this regard the author is influenced by Pruyser, who refers to this kind of process as "limnality" (1976). In other words, it is the ordeal of crossing one of life's "limits," that is of moving across one of life's significant boundaries.

The author elaborates on this process by stating that, "one day a person is married, the next day s/he is a widow or widower. One day s/he is a child with parents, the next day s/he is bereft of parents." The reader must bear in mind that physical movement plays a significant part in transition, for example in the case of bereavement it would be the movement to the funeral parlour, to the selection of a coffin, the journey from home to Church, or from the funeral parlour to the graveside, or the journey to the cemetery for burial, or finally cremation as a way of closing the chapter of life of one's beloved. Finally, the funeral or cremation service in itself has an important educative function. The service offers the Church an effective way of consoling the bereaved. It is an effective way of saying: "When death comes, there are things that we believe in." For example, the scriptures, prayers and hymns help us to focus on the Christian community's values and beliefs in order to interpret the meaning of the crisis of death. Let us now analyse the service of cremation. After the funeral worship service with the coffin in the church, the minister needs to prepare for another service to be performed at the interment of the ashes, after cremation. It is not advisable for the family to dispose of the ashes without proper closure. How the cremated remains are regarded and 
ultimately disposed of provide an indication of the direction the pastoral ministry would take for particular mourners. Some mourners may wish to use the ashes as a means of experiencing some form of presence of the deceased. In spite of the radically altered form of the body, people sometimes want to keep the ashes nearby in the home as a way of retaining a measure of personal presence of the deceased. This being the case, the option of cremation provides the only legal and practical way of keeping the remains at home. The morbidity of such an approach is indicative of the need to very realistically face the fact that death has terminated a relationship as it was known. In such a situation, the ministry of the church should provide sufficient support and strength for the bereaved so that they would be comforted and accept the reality of the loss.

\section{THE GARDEN OF REMEMBRANCE}

For most families, the inurnment of the ashes and subsequent placement in a columbarium, urn, or in a garden of remembrance, represents a means of disposing of the cremated remains and establishes a means of focus for remembering their deceased loved one. It can also serve as a means for recognizing the transition from body presence to body absence. A service of committal, especially when the ashes are placed in a niche, buried in a garden of remembrance, or are interred, reinforces the recollection process, again remembering with respect and reflecting with respect and remembrance on the way in which the past relationship is came to an end. If, however, such memorialization becomes a means of holding on to the person in order to maintain more than just memory by having a continuation of the relationship, the process is unhealthy. This is however unlikely, because someone who is intent on preserving the identity of the deceased in an attempt to continue a relationship with the deceased, will probably not choose cremation. S/he will rather elect burial, where the notion of the presence of the body in the grave offers a greater possibility for assuming the relationship to continue.

\section{BODY PRESENCE TO BODY ABSENCE}

It is important for the minister to help the family move into the third phase of mourning. The first category deals with the immediate situation when death occurs. The memorial service represents the second phase and the last one occurs with burial or dealing with the ashes. When the family arranges for the disposal of the ashes, it could indicate that they are fully prepared for the transition from body presence to body absence. In many circumstances it would be indicative of progress in the mourning process. The exception would 
be those instances where strewing the ashes forms part of a pattern of wanting to get rid of the deceased and of any recollection of him/her. With the strewing of the ashes, one of the most tangible points of reference for remembering the deceased is removed. There is no identifiable location of the bodily remains. For many families this may not pose a problem. Others may at a later stage experience it as a loss and may require special support in going through a process of remembering.

When the church grounds are used for dispersing ashes, it is important to set a place apart in the garden specifically for this purpose, and to call it the garden of remembrance. A service for the strewing of the ashes can be held there and a plaque with the name, date of birth and date of death of the deceased person could be placed on a wall of remembrance. Whenever families wish to commemorate the person, they could visit the garden of memories. This is the role the church can play in helping people deal with death and to finally bring to a close their process of mourning. The church through its minister can participate in the strewing ceremony when the minister leads a second committal service at the time when the ashes are actually scattered, thereby achieving the completion of the identifiable existence of the deceased but for the memories of him or her held by family and friends. Another way of remembering the deceased is to have a service at the beginning of each year commemorating those who had passed away during the previous year. This practice is familiar in many African churches and is known as "Tshebeletso ya selekana" - a service of completion of mourning. It is comforting and provides a source of healing especially for those who have lost family members. This practice again offers the opportunity to reinforce the process of recollection without encouraging morbid attempts at continuing a relationship with the deceased.

Finally, the church could have its own columbarium or garden of remembrance within the church grounds which would very much resemble the traditional churchyard symbolizing the solidarity of the Christian community in life and death. In ways such as these can the transition from body presence to body absence be assisted?

\section{CONCLUSION}

Bringing comfort to those in mourning has always been part of the mission and ministry of the church. Those who have had to come to terms with the death of a loved one remember the church as a source of comfort in trying times. The ministry focuses on a particular need and leads or guides people to start the process of mourning. At times, mere presence is all that is needed. I refer to this process of being with the people - "the theology of the 
presences." As the practice of cremation increasingly gains ground, much pastoral care would be required, especially among the African community. In conclusion, I wish to share with readers the story of a spouse who struggled to come to terms with the issue of cremation.

\section{LIGHT LIKE THE SUN}

Let us analyze the life experience of Mrs Newton, a woman who was facing the death of her father as it is told in her autobiography. Her father's imminent death meant that she had to start considering burial and with it, the option of cremation. She however refused to consider the latter as an option. In her autobiography she writes: "It was bad enough to die, without becoming a bonfire". Besides as she writes, she liked "the idea of burial of returning to the earth again, of enriching the soil and becoming part of nature". She was faced with the problem though that the rural churchyard was full, nor was there space in the city cemetery, where she did not want her father to be buried, for she "did not like the crowdedness, expensive, and squalid-cluttered graveyard; full of unending rows of graceless, ugly blobs of stone, each a memorial to some loved one, in mass a monstrous blight upon the land".

A young man charged with selling a plot in the cemetery for $\$ 1,700.00$ started talking to her and said to her: "if I had to do what you're doing today, I'd choose cremation!" to which Newton instinctively replied: "Never"

He however persisted and suggested that she visit the crematory in the cemetery. She finally agreed and took a ride to the cemetery chapel. There Mrs Newton wanted to know everything about cremation. The man explained to her that there were flowers on the altar and that warm colours were cascading through stained glass windows playing off against the white walls. The casket is brought in and the usual committal service for the dead is held. When the words "earth to earth, ashes to ashes, dust to dust" are pronounced, the casket is sprinkled with ashes and with dust. The attendant presses this electric button, upon which the casket sinks a foot below the floor, leaving only the flowers being visible. The priest pronounces the benediction, and the service is over. Then the casket is whisked away to the retort where, under the watchful eyes of a friend of the family, the body is reduced to ashes. The ashes in turn, are placed in a lovely urn, to be placed either in a niche in the chapel or given to relatives to dispose of as they wish.

Following this explanation, Mrs Newton is beginning to see the merit of cremation but still can't bear the thought of flames consuming her beloved father. 
Mrs Newton: "does it burn ... like bonfire?"

Man: "No! The body is consumed not by flames but by heat and light - light like sun".

That explanation stirred something in Mrs Newton.

Mrs Newton: “ ... light, like the sun. A sense of triumph came over me. Sun lit over father while he was working in his garden. I can imagine sunlight on his white head as he sat on the terrace reading. Then one can see the warmth of sunlight bringing life to growing things, falling benignly on the aging. When father's time comes, I told my aching heart, I should bring him here for cremation. This is how she decided in favour of cremation. She then used the money that would have been spent on a burial for a scholarship to educate young adults.

(Newmand 1978:46)

Continuing with her thoughts Mrs Newton said: "To me, he has not died. To these unknown students he is bringing light, like the sun." The purpose of narrating this story was to help us understand the suffering people's experience when having to decide on cremation. Once the minister understands this struggle, he or she would be in a position to prepare a service of closure, which would be truly meaningful especially when committing the ashes of beloved people. With this in mind, let us now analyze the suggested service of interment of ashes.

\section{SERVICE OF INTERMENT ASHES}

When preparing such a service, especially in the case of Christians, it is worth remembering that many of them had hymns that were very dear to them during their lifetime. and it is important to find out from the family whether there are any such hymns they would like sung. In this service the pastor is helping the family to remember or commemorate the life of the deceased. The main aim is to help them close the journey of their grief. Normally the ashes come in a small cardboard box which is enclosed in a small plastic container. The minister should have a container in which the ashes can be placed. On the day of the ceremony in the garden of memories, the minister will invite the people to gather near the hole prepared for the interment of the ashes. The following liturgy could be followed: 
Hymn: a favorite song of the deceased or the loved ones is sung, where after the minister will say the following words from scripture:

Minister: When we were baptized in Christ Jesus, we were baptized into his death. We were buried therefore with him by baptism into death, so that, as Christ was raised from the dead by the glory of the father, we too might live a new life. For if we have been united with Christ in a death like his, we will certainly be united with him in a resurrection like his. Other passages of scripture dealing with death can also be recited. The main focus is to remind people of the fact that for Christians death is not the end.

\section{RECITAL FROM SCRIPTURES}

Our help is in the name of the Lord, Who made heaven and earth.

(Ps 124:8)

I am the resurrection and the life, says The Lord, those who believe in me, even Though they die will live, and everyone Who believes and live in me shall never die.

(Jn 11:25-26)

God is our refuge and strength, A very present help in trouble. Therefore we will not fear.

Peace I leave with you, my

Peace I give to you. I do

Not give to you as the world gives.

Do not let your hearts be troubled,

And do not let them be afraid.

The eternal God is your dwelling place, And underneath are the everlasting arms. 
I am the alpha and omega, The beginning and the end, the First and the last. I was dead And behold I am alive forever and ever, And I have the keys of Death and Hades. Because I live, you also will live.

(Rv 21:6, 22:13, 1:17-18; Jn 14:19)

Do not be afraid I am the First and the last, and the Living one, I was dead, And behold, I am alive forever And forever.

(Rv 1:17-18)

Blessed are those who mourn, For they will be comforted.

(Mt 5:4)

HYMN

PRAYER

Eternal God, maker of heaven and earth: You formed us from the dust of the earth, and by your breath you gave us life. We glorify you.

Jesus Christ, the resurrection and the life: You are the comforter of all who are mourning/grieving/sorrowing, our sure confidence and everlasting hope. We worship you.

Eternal God, through the power of the Holy Spirit, our guide we acknowledge the uncertainty of our life on earth. We are given a mere handful of days, and the span of our life seems nothing in your sight. All flesh is as grass; and all its beauty is like the flowers of the field. The grass withers, the flowers fade, but your word will stand forever. In this is our hope, for you are our God. Even in the valley of the shadows of death, you are with us.

To you, oh blessed Trinity, be the power, glory, honor, and majesty from ages to ages. Be unto you most holy God. Amen. Let us join the family in prayer. (The congregation will say the Lord's Prayer together) 


\section{CONGREGATION}

Our father who art in heaven hallowed be your name;

Your Kingdom come, your will be done on earth as in heaven.

Give us this day our daily bread.

Forgive us our sins, as we forgive those who sinned against us

Save us from the time of trials, and deliver us from evil.

For the Kingdom, the power, the glory is yours, now and forever.

Amen

\section{FAMILY}

At this stage the minister will invite members of the family to move closer to the last resting place.

The minister will now say the following words:

Minister: Finally, my brother and sisters, whatever is true, whatever is noble,

whatever is right, whatever is pure, whatever is lovely, whatever is admirable - if anything is excellent or praiseworthy - think about those things. And the God of peace will be with you.

A member of the family then hands the ashes in the urn to the minister. The minister will say the following words:

Minister: "We commit the ashes of our brother/sister" (calling the name of the deceased) to their resting place. (Pour some of the ashes into the hole, then invite the family to follow, and lastly, a close friend could be invited to also pour ashes into the hole or alternatively place the urn in the plot.)

Minister: "Blessed are the dead who died in the Lord. From now on they will rest from their labor, for their deeds will follow them."

The minister will begin to close the hole and will invite members to join him in doing so. After the committal and the closing of the hole, the minister will invite a member of the family to unveil the plague. 


\section{PLAQUE}

The minister will ask one of the family members to uncover the plaque:

Minister: "We dedicate this plaque in memory of our brother/sister (name) who died on (date). Blessed are the dead who died in the Lord. From now on they will rest from their labor, for their deeds will follow them. Rest eternal grant unto him/her. And let your light perpetually shine upon him/her."

\section{HYMN}

"Abide with me" or "What a friend we have in Jesus" could be sung.

\section{PRAYER}

Let us pray.

Our father, we thank you for every fond remembrance that comes to us in this place. As it reminds us of the past, and of those we continually miss, let it speak to us also of what is yet to be through our Lord Jesus Christ. Amen.

Your Kingdom in heaven remains forever and there you reign eternally. We worship you. Our hope is in you, through Jesus Christ your son, our Lord. Our comfort is from you, God the Father, God the Son, God the Holy Spirit. Amen.

And now receive today our thanksgiving and praise, for all you have done, are doing, and will yet do in sowing love that conquers death. Let our sorrow pass and our joy be full. Amen

\section{BENEDICTION}

Now receive the blessing of God almighty.

The God of peace, who brought back from the dead our Lord Jesus Christ, make you complete in everything good, so that you may do God's will, working among us that which is pleasing in God's sight, through Jesus Christ, to whom be the glory from ages to ages. Amen

\section{CONCLUSION}

It is a help to the family when members of the congregation prepare tea for the family and those who came to show fellowship with them. This deed is 
another way of helping them to achieve closure and expresses the congregation's caring.

The United Presbyterian Worship Book captures some pastoral elements worth quoting. It says:

God consoles us in all our afflictions, so that we may be able to console those who are in any affliction. For just as the suffering of Christ are abundant for us.

(Service for Pastoral Care, 1990:43)

This is another pastoral way of caring for those afflicted by death. According to Tillich "A beautiful or noble deed is a deed to be praised" (Tillich 1980:4). In conclusion, this is a gift a minister could share with those who are mourning.

\section{Works consulted}

Hickman, H I 2000. The Book of United Methodist Church Worship. Nashville, TN: United Methodist Publishing House.

Hiltner, S 1949. Pastoral Counseling. Nashville, TN: Abingdon.

Gunton, C 1989. Service Book of The United Reformed Church. Oxford: Oxford University Press.

Job, R P 2003. A guide to prayer. Nashville, TN: The Upper Room.

Newman, R 1978. The autobiography of Mrs Newton. London: Cressent. Pruyser, P W 1976. The minister as diagnostician. Philadelphia, PA: Westminster. Thurman, H 1984. Deep is the hunger. Nashville, TN: Friends United Press.

Tillich, P 1980. The courage to be. New Haven, CT: Yale University Press.

UPCSA 1993. Book Of Common Worship. Louisville, KY: Westminster John Knox. (Prepared by the Unit on Theology and Worship.)

UPCSA 1995. Service for occasions of Pastoral Care. Louisville, KY: Westminster John Knox. (Prepared by the Unit on Theology and Worship.) 